\title{
Morphological Observation of Alexandrium tamarense (Lebour) Balech, A. catenella (Whedon et Kofoid) Balech and One Related Morphotype (Dinophyceae) in Korea
}

\author{
Keun-Yong Kim ${ }^{*}$, Matoko Yoshida ${ }^{1}$, Yasuwo Fukuyo ${ }^{2}$ and Chang-Hoon Kim \\ Department of Aquaculture, Pukyong National University, Busan 608-737, Korea \\ ${ }^{1}$ Laboratory of Coastal Environmental Sciences, Faculty of Fisheries, Nagasaki University, Nagasaki 852-8521 and \\ ${ }^{2}$ Asian National Environmental Science Center, The University of Tokyo, Tokyo 113-8657, Japan
}

\begin{abstract}
Twenty-nine culture strains belonging to the genus Alexandrium Halim (Dinophyceae) were established from water column or sediments in Korea. Seventeen isolates were identified as A. tamarense (Lebour) Balech, eight isolates as A. sp. cf. catenella and one as A. catenella (Whedon et Kofoid) Balech according to the presence or absence of a ventral pore, the shape of the posterior sulcal plate and the sulcal width. Three isolates were unable to be identified due to considerable distortion of thecal plates and lack of enough materials, but typical of $A$. tamarense and/or A. catenella. The overall cell shape of $A$. tamarense was usually longer than wide. The posterior sulcal plate was definitely longer than wide dorsoventrally, and sulcus extended posteriorly without apparent widening. They were distributed in three major coasts of Korea. In contrast, the cell shape of $A$. sp. cf. catenella was generally anterior-posteriorly flattened. The transversal axis of the posterior sulcal plate was always longer than the longitudinal, or both axes were nearly equal in length. Its sulcus was broader than that of $A$. tamarense and widened in the direction of antapex about 1.5 times. This morphotype existed in nearshore and offshore waters of the southern Korea sea. One of $A$. catenella isolates from Jinhae Bay showed no conspicuous differences with A. sp. cf. catenella except for the consistent absence of a ventral pore.
\end{abstract}

Key Words: Alexandrium tamarense, Alexandrium catenella, Alexandrium sp. cf. catenella, geographical distribution, morphological observation

\section{INTRODUCTION}

About 50 marine dinoflagellates are known to be capable of producing potent toxins (Sournia 1995). They cause a variety of gastrointestinal and neurological illnesses to human, and huge economic losses through the food chain (Hallegraeff 1993). Some species in the genus Dinophysis Ehrenberg and Alexandrium Halim can contaminate shellfish with toxins even at low cell concentrations (Hallegraeff 1993).

Since the first occurrence of paralytic shellfish poisoning (PSP) in 1927 (Sommer and Meyer 1937), some dinoflagellates (Balech 1995; Taylor et al. 1995), cyanobacteria (Sivonen 1996) and bacteria associated with toxic dinoflagellates (Gallacher et al. 1997) have been convicted of PSP toxin production. The genus

*Corresponding author (koby0323@hanmail.net)
Alexandrium consists of about 30 species including as many as 10 toxigenic species (Balech 1995; Taylor et al. 1995). In spite of their recent redescription by Balech (1995) and Yoshida (2000), several species groups are still open to debate on their speciation. Especially, $A$. tamarense (Lebour) Balech, A. catenella (Whedon and Kofoid) Balech and A. fundyense Balech (or the tamarensis complex) have received extensive attention from many scientists due to their taxonomic difficulty (Taylor 1975, 1984; Schmidt and Loeblich 1979; Cembella and Taylor 1986), potent toxicity (Cembella et al. 1987; Kim et al. 1993; Anderson et al. 1994), worldwide distribution (Hallegraeff 1993) and possibility for human-assisted dispersal (Hallegraeff 1993; Scholin et al. 1995).

Cho (1978) reported the first HAB by one of Alexandrium species at Jinhae Bay, Korea. Two PSP incidents resulting in human deaths from eating toxified mussels broke out (Chang et al. 1987; Jeon et al. 1988; Arakawa et al. 1989; Lee et al. 1997), and Han et al. (1992) 
reported that the causative organism was A. tamarense. Kim and Lee (1996) and Kim and Shin (1997) reported vernal blooming, toxicity and resting cysts distribution of Alexandrium spp. at Jinhae Bay, the most notorious place for annual shellfish poisoning. Since then, continuous PSP monitoring has been conducted around shellfish farming areas.

The taxonomic studies of Alexandrium in Korea were conducted by several researchers (Shim et al. 1981; Balech 1985, 1995; Lee et al. 1993; Han et al. 1992, 1993; Yoo et al. 2000). A. affine (Inoue et Fukuyo) Balech, $A$. catenella, A. fraterculus (Balech) Balech, A. insuetum Balech, A. leei Balech and A. tamarense have been known in Korea to date. The taxonomic studies as well as PSP monitoring were, however, conducted at limited areas of southern coasts of Korea including Jinhae Bay.

Here, we conducted a morphological observation of Alexandrium isolates established from various parts of Korean coasts. This study was also undertaken as a step toward surveying PSP toxin productivity, and understanding genetic diversity and geographical distribution of Alexandrium populations in Korea.

\section{MATERIALS AND METHODS}

\section{Establishment of Culture Strains and Maintenance}

Phytoplankton samples were collected by towing a 20 $\mu \mathrm{m}$ mesh plankton net. The samples were moved to the laboratory without fixation. A vegetative cell or a chainforming unit was picked out with a fine-tipped pipette and was successively transferred into other tissue culture wells containing sterile seawater to minimize bacterial contamination. Only one cell or one chain-forming unit was finally transferred into a test tube containing sterile SWIIm medium (Iwasaki 1961). The clonal culture was maintained at $15-20^{\circ} \mathrm{C}$ and $80-100 \mu \mathrm{mol} \cdot \mathrm{m}^{-2} \cdot \mathrm{s}^{-1}$ of cool white light under 14L:10D photocycle.

Sediments were sampled with a gravity corer, moved to the laboratory on ice at dark and stored at $4^{\circ} \mathrm{C}$ dark room until ready to use. A portion of the sediments was briefly sonicated and strained through a $125 \mu \mathrm{m}$ polyester sieve to remove larger particles and then concentrated onto a $20 \mu \mathrm{m}$ sieve. Individual resting cysts were picked out from the screened sediment sample, placed into each tissue culture well containing sterile SWII medium (Iwasaki 1961) and incubated under various germination conditions. Two cells or chain-forming units divided from a planomeiocyte after germination were separated, washed several times with micropippet and

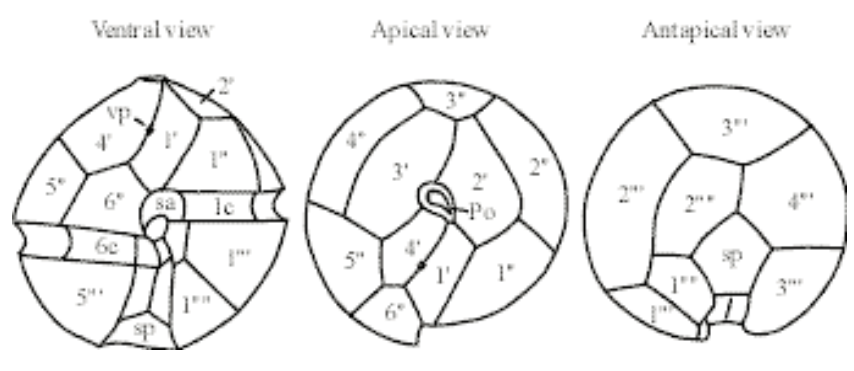

Fig. 1. Schematic of Alexandrium with ventral, apical and antapical views (redrawn from Steidinger and Tangen 1997).

grown as previously stated.

Detailed sampling sites, dates and origins were shown in Table 1 and Fig. 3. Dino-6 was kindly provided by Prof. J. G. Park of Inje University, Korea.

\section{Observation of Morphology}

Vegetative cells of each clonal culture were photographed with a light microscope (Olympus BX50) using differential interference contrast. Thecal plates were observed after dissecting the theca of cells with 5\% sodium hypochlorite and staining with the Imamura and Fukuyo's solution (Yuki and Fukuyo 1992). The terminology used in this work was adopted from Steidinger and Tangen (1997) (Fig. 1).

\section{RESULTS}

\section{Descriptions}

Twenty-nine clonal cultures established from various parts of Korean coasts were identified (Table 1). All isolates shared the typical morphological features of Alexandrium tamarense/catenella (see Kim 2001 for the detail). All isolates except one (Dino-6) were hardly distinguishable from one another by their overall cell shape and detailed thecal features. However, some relatively conservative characters were found as follows; the flattening of the cell shape, the shape of the sp and the 2 "'", and sulcal width.

\section{Alexandrium tamarense (Lebour) Balech 1985}

Fig. 2A-H

Balech 1985, p. 38, Fig. 2; Balech and Tangen 1985, p. 335, Fig. 1; Fukuyo 1985, p. 532, Fig. 2A-G; Fukuyo, Pholpunthin and Yoshida 1988, p. 13-14, Pl. II, 6-11; Hallegraeff, Bolch, Blackburn and Oshima 1991, p. 583, Fig. 33-42; Lee, Park and Kim 1993, p. 6, Fig. 3; Han, Jeon and Kim 1992, p. 1584, Fig. 2; Han, Jeon and Yoon 1993, 
Table 1. Information of Alexandrium isolates identified in this study

\begin{tabular}{|c|c|c|c|c|}
\hline Strain Code $\mathrm{a}^{\mathrm{a}}$ & Species Designation $^{\mathrm{b}}$ & Ventral Pore & Sampling Site & Sampling Date \\
\hline BSW97 & A. tamarense & $\mathrm{w}$ & Busan & Jun. 1995 \\
\hline CMC98a & A. tamarense/catenella & $\mathrm{w}$ & $34^{\circ} 04^{\prime} \mathrm{E} 128^{\circ} 22^{\prime} \mathrm{N}$ & Jun. 1998 \\
\hline CMC98b & A. sp. cf. catenella & $\mathrm{w}$ & $"$ & $"$ \\
\hline Dino-6 & A. catenella & $\mathrm{w} / \mathrm{o}$ & Jinhae Bay & Jun. 1997 \\
\hline DPC95a & A. sp. cf. catenella & $\mathrm{w}$ & Dadaepo, Busan & $"$ \\
\hline DPC95b & A. sp. cf. catenella & $\mathrm{w}$ & $"$ & $"$ \\
\hline DPC95c & A. sp. cf. catenella & $\mathrm{w}$ & $"$ & $"$ \\
\hline JDC00a & A. tamarense & $\mathrm{w}$ & Jindong, Jinhae Bay & Mar. 2000 \\
\hline JDW0004-13 & A. tamarense & $\mathrm{w}$ & $"$ & Apr. 2000 \\
\hline KJC97a & A. tamarense & $\mathrm{w}$ & Geojedo & Nov. 1997 \\
\hline KMC98a & A. sp. cf. catenella & $\mathrm{w}$ & $34^{\circ} 19^{\prime} \mathrm{E} 127^{\circ} 33^{\prime} \mathrm{N}$ & Aug. 1998 \\
\hline SJC95a & A. tamarense & $\mathrm{w}$ & Sujeongri, Jinhae Bay & Sep. 1995 \\
\hline SJC95b & A. tamarense & $\mathrm{w}$ & $"$ & $"$ \\
\hline SJC00a & A. tamarense & $\mathrm{w}$ & $"$ & Mar. 2000 \\
\hline SJW9704-3 & A. tamarense & $\mathrm{w}$ & $"$ & Apr. 1997 \\
\hline SJW9704-6 & A. tamarense & $\mathrm{w}$ & $"$ & $"$ \\
\hline SJW9704-15 & A. tamarense & $\mathrm{w}$ & $"$ & $"$ \\
\hline SJW0003-11 & A. tamarense & $\mathrm{w}$ & $"$ & Mar. 2000 \\
\hline SJW0007-7 & A. sp. cf. catenella & $\mathrm{w}, \mathrm{w} / \mathrm{o}$ & $"$ & Jul. 2000 \\
\hline SJW0007-8 & A. sp. cf. catenella & $\mathrm{w}, \mathrm{w} / \mathrm{o}$ & $"$ & $"$ \\
\hline SSW0006-3 & A. tamarense & $\mathrm{w}$ & Seoseang & Jun. 2000 \\
\hline SSW0006-7 & A. tamarense & $\mathrm{w}$ & $"$ & $"$ \\
\hline SOW0004-8 & A. tamarense/catenella & $\mathrm{w}, \mathrm{w} / \mathrm{o}$ & $34^{\circ} 14^{\prime} \mathrm{E} 127^{\circ} 52^{\prime} \mathrm{N}$ & Apr. 2000 \\
\hline SOC004a & A. tamarense & $\mathrm{w}$ & $"$ & $"$ \\
\hline ULW9903 & A. tamarense & $\mathrm{w}$ & Ulsan & Mar. 1999 \\
\hline YOC98a & A. tamarense & $\mathrm{w}$ & $35^{\circ} 51^{\prime} \mathrm{E} 125^{\circ} 24^{\prime} \mathrm{N}$ & Dec. 1998 \\
\hline YOC98b & A. tamarense/catenella & $\mathrm{w}$ & $"$ & $"$ \\
\hline YOC98c & A. tamarense & $\mathrm{w}$ & $35^{\circ} 51^{\prime} \mathrm{E} 125^{\circ} 37^{\prime} \mathrm{N}$ & $"$ \\
\hline YSC98a & A. sp. cf. catenella & $\mathrm{w}$ & Yeosu & Nov. 1998 \\
\hline
\end{tabular}

a Dino-6 was provided by Prof. J. G. Park of Inje University, Korea.

${ }^{\mathrm{b}}$ A. tamarense/catenella was unable to identify at the species level, but typical of A. tamarense and/or A. catenella.

p. 10, Fig. 2; Balech 1995, p. 38-41, Pl. VI, Fig. 1-40, VII, Fig. 1-9; Steidinger and Tangen, 1997, p. 500, Pl. 36; Yoo, Fukuyo, Cheun, Lee and Kim 2000, p. 28, Fig. 2-17.

Synonyms: Gonyaulax tamarensis Lebour 1925, Gonyaulax tamarensis var. excavata Braarud 1945, Gonyaulax excavata Balech 1971, Protogonyaulax tamarensis Taylor 1979, Gessnerium tamarensis Loeblich and Loeblich 1979, Alexandrium excavatum Balech and Tangen 1985.

Cells were usually longer than wide (Fig. 2A-C). Length of cells was 21.5 to $39 \mu \mathrm{m}$, and width 18.5 to 36.5 $\mu \mathrm{m}$. The width/length ratio was in the range of 0.96-1.17. Cells were usually single and rarely in pairs. All examined cells possessed a typical vp (Fig. 2D-F). The sp was definitely longer than wide dorsoventrally (Fig. 2G, H). It was rectangular-shaped with the convex dorsal end or subpentagonal-shaped with two obtuse-angled margins. Usually the margin with the 4 "' was much shorter than that with the 2 "'". Sulcus was narrow and extends poste- riorly without apparent widening (Fig. 2C). The shape of the 2"" was rather variable; either transversely or dorsoventrally elongated (Fig. 2G, H).

Han et al. (1992), Lee et al. (1993) and Balech (1995) reported the occurrence of this species at Jinhae Bay in Korea. The first monospecific HAB broke out in 1997 at the same area (Yoo et al. 2000). Han et al. (1993) reported the occurrence of this taxon at Gamraepo, Masan Bay, Chilchundo and Yeosuhae Bay. In this study, 17 isolates from 8 areas were identified; Busan (BSW97), Geojedo (KJC97a), Jinhae Bay (JDC00a, JDW0004-13, SJC95a, SJC95b, SJC00a, SJW9704-3, SJW9704-6, SJW9704-15, SJW0003-11), Seoseang (SSW0006-3, SSW0006-7), Ulsan (ULW9903), off the coast of the Yellow Sea (YOC98a, YOC98c) and the southern Korea sea (SOC00a) (Fig. 3).

Alexandrium sp. cf. catenella

Fig. 2I-P 

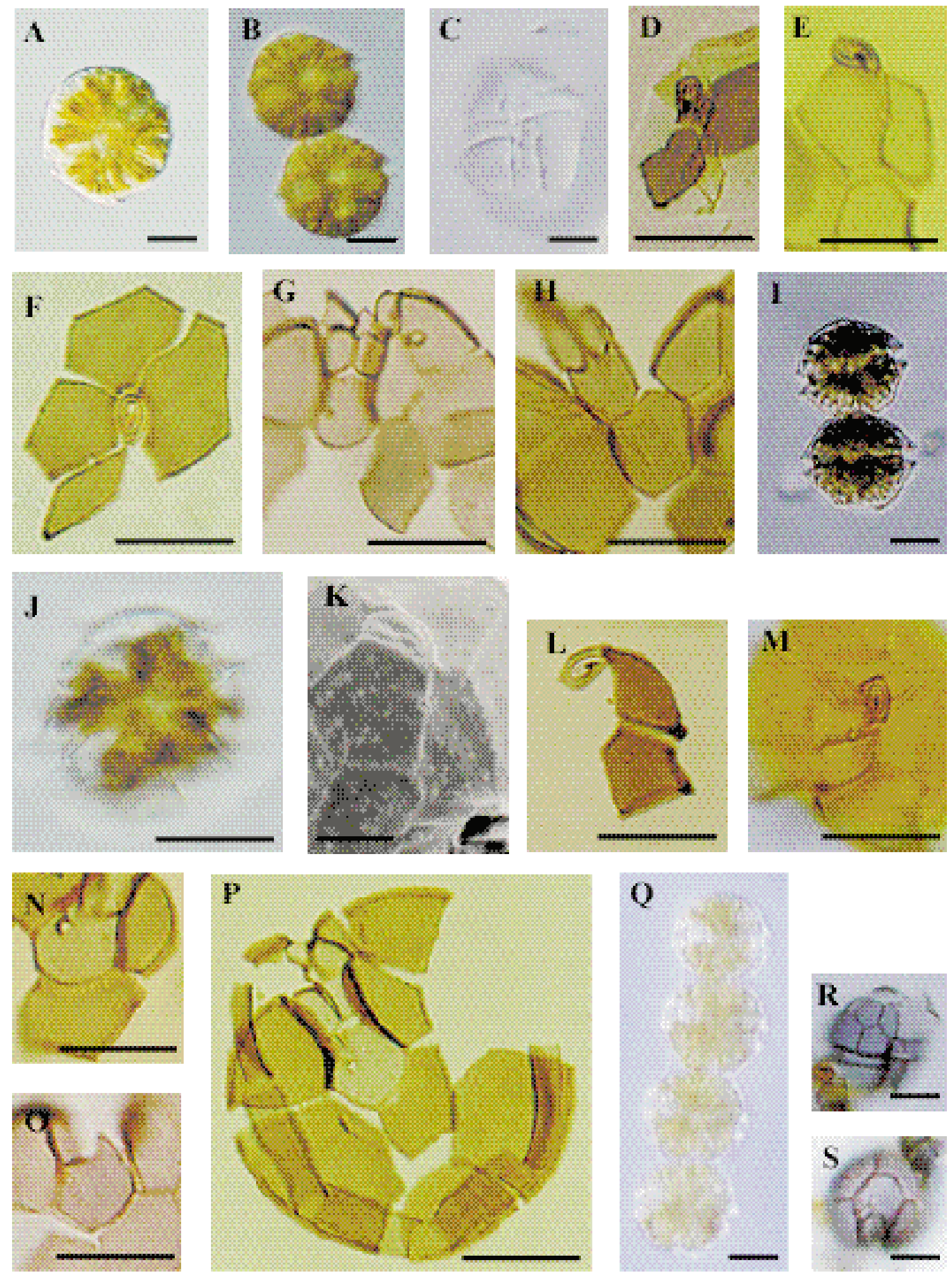

Fig. 2. LM and SEM observation of Alexandrium tamarense (A-H), A. sp. cf. catenella (I-P) and A. catenella (Q-S) isolates in Korea (All cultured specimens except I).

A, A vegetative cell in ventral view; B, Vegetative cells in a pair; C, An empty theca showing posteriorly extending sulcus without apparent widening; D-F, APC (apical pore complex) and the rhomboidal 1' with a ventral pore; G-H, The dorsoventrally long sp and the 2". I. A field material; vegetative cells forming a chain from the same sampling site where SJW0007-7 and SJW0007-8 were isolated; J, A vegetative cell in ventral view showing the posteriorly widening sulcus. K-M. APC and the 1'. L and M: The 1' with and without a ventral pore of which micrographs were taken from the same clonal culture, SJW0007-7; N-P, The transversally long sp and the 2"; Q, A chain of four cells; R, The 1' without a ventral pore; S, The transversally long sp plate. E, F, H, L, M and O: reverse images. Scale bars $=10 \mu \mathrm{m}$ except $\mathrm{K}(5 \mu \mathrm{m})$. 
Cells were generally flattened anterior-posteriorly (Fig. 2I-J). The width/length ratio varied from 0.84 to 1.03. Length of cells was 21.5 to $32 \mu \mathrm{m}$, and width 24 to $32 \mu \mathrm{m}$.

Two clonal cultures (SJW0007-7 and SJW0007-8) were established from water column. The initial cells in the field sample were unequivocally compressed and formed chains of 2-4 cells (Fig. 2I). Once in culture medium, they tended to swim solitarily not being concatenated and became rather isodiametric in shape. Interestingly, both cells with and without a vp were observed simultaneously in the clonal cultures (Fig. 2L, $\mathrm{M})$. Vegetative cells of other cultures had a consistent vp. The $\mathrm{sp}$ was the rectangular- to pentagonal-shape (Fig. $2 \mathrm{~N}-\mathrm{P})$. The transversal axis was always longer than the longitudinal, or both axes were nearly equal in length. When the shape was pentagonal, slightly convex dorsal margins touching the $4^{\prime \prime \prime}$ and the 2 "'" were nearly equal in size forming an acute angle (Fig. 2P). Sulcus was broader than that of $A$. tamarense and widened in the direction of antapex about 1.5 times (Fig. 2J).

The 2 "'" was always transversely elongated (Fig. $2 \mathrm{~N}$, P).

In this study, eight isolates from 5 places were identified; Dadaepo (DPC95a, DPC95b, DPC95c), Jinhae Bay (SJW0007-7, SJW0007-8), Yeosu (YSC98a) and the nearshore and offshore southern Korea sea (CMC98b, KMC98a) (Fig. 3).

\section{Alexandrium catenella (Whedon et Kofoid) Balech 1985} Fig. 2Q-S

Balech 1985, p. 37, Fig. 2; Fukuyo 1985, p. 532, Fig. 2HN; Hallegraeff, Steffensen and Wetherbee 1988, p. 534, Fig. 1, 2; Hallegraeff, Bolch, Blackburn and Oshima 1991, p. 580, Fig. 17-32; Lee, Park and Kim 1993, p. 7, Fig. 4; Balech 1995, p. 48-50, Pl. X, Fig. 1-31, Pl. XI, Fig. 1-12; Steidinger and Tangen 1997, p. 492, Pl. 35; non: Postek and Cox 1976, p. 89, Fig. 2-11.

Synonyms: Gonyaulax catenella Whedon and Kofoid 1936, Protogonyaulax catenella Taylor 1979, Gessnerium catenellum Loeblich and Loeblich 1979, Gonyaulax washingtonesis Hsu 1967

Length and width of vegetative cells varied from 21 to $23.5 \mu \mathrm{m}$ and from 23 to $25 \mu \mathrm{m}$, respectively. Cells were slightly anterior-posteriorly compressed and commonly formed a chain of 4 cells (Fig. 2Q). No definite difference from $A$. sp. cf. catenella existed in any traits such as the overall cell shape and detailed thecal features including the sp (Fig. 2S) except for the consistent absence of the

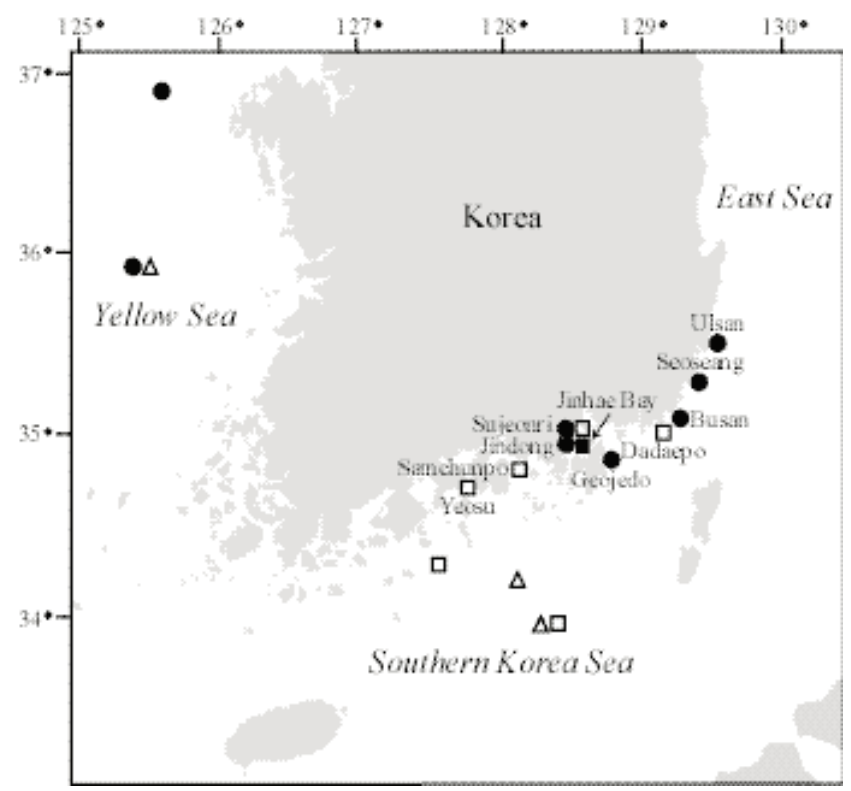

Fig. 3. Geographical distribution of Alexandrium isolates in Korea.

-, A. tamarense; $\square$, A. sp. cf. catenella; $\mathbf{\square}$, A. catenella; $\triangle$, unable to identify at the species level but typical of $A$. tamarense and/or A. catenella.

vp (Fig. 2R).

This dinoflagellate has been observed previously at Jinhae Bay in Korea (Lee et al. 1993; Balech 1995). In this study, one isolate (Dino-6) from Jinhae Bay was identified (Fig. 3).

\section{Unidentified Isolates}

We failed to correctly identify three isolates. CMC98a and YOC98b showed a considerable variation of the thecal formulae probably because of the aged culture and unfavorable culture conditions. The appropriate species assignment was also impossible for SOW0004-8 due to deformed thecal plates and lack of enough material. The former two isolates always had a prominent $\mathrm{vp}$, whereas the latter contained cells with and without a vp in a single culture. Other features were not quite different from those of other isolates identified in this study.

\section{DISCUSSION}

The genus Alexandrium is distinct from other genera in Gonyaulacales in that they have homologous plate formula, poorly developed lists, no horns, no spines, a large comma-shaped apical pore, 1-1.5 width girdle displacement and generally smooth-walled resting cysts (Balech 1995; Taylor et al. 1995; Steidinger and Tangen 1997). 
Unlike other dinoflagellate genera or species which have easily distinguishable morphological characters under light microscope, the species assignment of Alexandrium relies on fine-scale morphological features such as size, overall cell shape, chain formation, cingular and sulcal excavation, sulcal list development, the shape of the Po, the $1^{\prime}$ and the $66^{\prime \prime}$, and all the sulcal plates, especially the sp, the sa and the ssa (Balech 1995; Taylor et al. 1995; Steidinger and Tangen 1997; Yoshida 2000).

Misinterpretation of the connection between the Po and the $1^{\prime}$, and misdesignation of the ssa for the $1^{\prime \prime \prime}$ and the 1 "' for the $1 \mathrm{p}$ led to a proliferation of Alexandrium generic names such as Gonyaulax Diesting 1886, Heteraulacus Diesting 1850, Pyrodinium Plate 1906, Alexandrium Halim 1960, Gessnerium Halim 1967 and Protogonyaulax Taylor 1979 (Steidinger 1971, 1990; Loeblich and Loeblich 1979; Taylor 1979, 1984; Balech 1989, 1995; Steidinger and Moestrup 1990). The problem recently has been settled down by Balech $(1989,1995)$.

After the correction of the optically reversed epitheca description of $A$. tamarense icotype, the discrimination among $A$. acatenella (Whedon and Kofoid) Balech, $A$. catenella, A. tamarense (and A. fundyense) has been much more complicated (Taylor 1975, 1984; Steidinger 1990; Balech 1995). To date, the most remarkable features distinguishing $A$. tamarense from $A$. catenella and $A$. fundyense are presence or absence of a ventral pore, cell width and chain formation (Taylor 1984; Balech 1995; Taylor et al. 1995).

In the initial field samples, two isolates (SJW0007-7 and SJW0007-8) were relatively easily characterized due to the tendency to be concatenated and the anterior-posteriorly flattened cell shapes that were noted only for $A$. catenella. However, once the isolates were grown in vitro, the character to form a chain was lost, and the cell flattening also became less prominent probably because of the different growth environment. Such morphological characteristics may be changed under artificial culture conditions as well as different ecological niche, different life cycle stage and other influences (Taylor 1984; Cembella and Taylor 1986). Thus, when one tries to establish a culture strain prior to physiological, biochemical and molecular biological experiments the taxonomic problems become serious.

The resting cysts of $A$. tamarense and A. catenella are hardly distinguishable (Fukuyo 1985), and scarcely are the cells accustomed to in vitro culture conditions when they excyst, so some degree of phenotypic variation is inevitable. To reduce confusion in the culture-based tax- onomy, simultaneous identification of preserved field materials has to be followed by the establishment of a culture strain from water column. Also, when establishing culture strains from sediment resting cysts, it is desirable to observe the thecal plates as soon as possible after several cell divisions of a planomeiocyte.

Though the ventral pore was not described in both icotypes of A. tamarense (Lebour 1925) and A. catenella (Whedon and Kofoid 1936), it is now recognized as the most reliable character for differentiating $A$. tamarense from A. catenella and A. fundyense (Balech 1995; Steidinger and Tangen 1997). However, in the case of SJW0007-7, SJW0007-8 and SOW0004-8, both cells with and without a pore co-occurred in each clonal culture. Despite stability of its existence in a single culture (Schmidt and Loeblich 1979; Balech and Tangen 1985; Cembella and Taylor 1986; Balech 1995), validity of the ventral pore as a specific character remains open to debate on account of uneasiness to observe in newly divided cells (Balech and Tangen 1985), conceivability of a cryptic pore invisible by a light microscope (Cembella and Taylor 1986) and its failure to follow the mendelian segregation in an interbreeding experiment between two morphospecies, A. fundyense and A. tamarense (Anderson et al. 1994). Thus, there is a possibility that we failed to find the pore in above three cultures because of its invisibility or crypticness. But a more reasonable cause of coexistence of the trait even in a clonal culture appears to be its expression by multiple genes, and its existence may be susceptible to environmental influences (Cembella and Taylor 1986; Anderson et al. 1994; Gallagher 1998).

Recent phylogenetic analysis of $A$. tamarense, $A$. catenella and $A$. fundyense also revealed independent clustering on this fine-scale morphological feature (Scholin et al. 1994). Thus, whether possession of the ventral pore is really a good trait to be used for species designation is open to further discussion. When A. taylori Balech comes in our consideration, the taxonomic problem becomes more realistic. Considerable variation in the $1^{\prime}$ was reported; it is pentagonal to romboidal with and without a ventral pore(s) from the type locality (Delgado et al. 1997).

Since all our isolates except Dino-6 had a ventral pore (including three isolates with and without one), we shifted emphasis on the sp, sulcal widening and the 2 "'". Then, the isolates were divided into $A$. tamarense and $A$. sp. cf. catenella, though we had to admit that the detailed features were phenotypic and such delineation might be 
subjective. The sp of $A$. tamarense was definitely longer than wide dorsoventrally. In contrast, the transversal axis of the sp of $A$. sp. cf. catenella was always longer than the longitudinal, or both axes were nearly equal in length. However, the shape of the sp seems to follow the overall cell shape that is susceptible to environmental changes; namely, anterior-posteriorly compressed cells have transversely longer $\mathrm{sp}$ than wide and vice versa.

The sulcal widening of $A$. sp. cf. catenella was always broader than that of $A$. tamarense. A. sp. cf. catenella had the transversely elongated 2"', , a relatively conserved character, whereas A. tamarense had both transversely and dorsoventrally elongated one. In the meanwhile, there was no difference between $A$. catenella and $A$. sp. cf. catenella except for the absence of the ventral pore. Yoshida (2000) also recognized the sp as a critical taxonomic criterion and inferred the Alexandrium evolution from its morphological change. However, the overlap and variation of such morphological characteristics especially in artificial culture conditions can depreciate their importance in discerning the distinctiveness of these morphotypes. Thus, when the distinction is likely to be obscure one has to rely on statistical data. To confirm whether above-mentioned morphological criteria had a real taxonomic value, partial sequences of LSU rDNA were investigated. The result supported the validity of these modest differences, and $A$. sp. cf. catenella was phylogenetically homogeneous with $A$. catenella Dino-6 (Lee et al. 1998; Kim 2001).

When morphologically closely related $A$. acatenella, $A$. excavatum (Braarud) Balech, $A$. fundyense and $A$. tropicale Balech come in our consideration, the taxonomic problem will be much more complicated, if not impossible. Specially, A. fundyense (= Gonyaulax tamarensis var. excavata) was distinguishable from A. tamarense (= G. tamarensis var. tamarensis) by the absence of a ventral pore with no other clear morphological or physiological differences (Schmidt and Loeblich 1979).

In spite of bringing about much taxonomic confusion, we reported, for the first time, existence of toxigenic Alexandrium populations in all three major coasts of Korea. In this study, the existence of the potential "seedbed" of Alexandrium resting cysts and the occurrence of vegetative cells were first reported off the coasts of the Korean sea. It implies that there is a possibility that their population can occur as a bloom-forming unit at the nutrient-rich frontal region after germination.

Attempts to elucidate the phylogenetic relationship of Alexandrium species have been aggressively made with biochemical, physiological and molecular tools. Many research groups showed a clear discordance between classic morphotaxonomy and subcellular traits (see Scholin 1998 for review). PSP toxin profiles (Cembella et al. 1987; Kim et al. 1993; Anderson et al. 1994; Parkhill and Cembella 1999) and rDNA sequences (Scholin et al. 1994; Medlin et al. 1998) seem to be good indicators to understand population biogeography and dispersal of Alexandrium population, which cannot simply be explained using simple morphological features. Thus, more intensive analyses using physiological or molecular data are needed to perceive their biogeography and dispersal mechanism in Korea.

\section{ACKNOWLEDGEMENTS}

This work was supported by the International Cooperation Research Program of the Ministry of Science \& Technology and by grant No. R02-2000-00226 from the Korea Science \& Engineering Foundation.

\section{REFERENCES}

Anderson D.M., Kulis D.M., Doucette G.J., Gallagher J.C. and Balech E. 1994. Biogeography of toxic dinoflagellates in the genus Alexandrium from the northeastern United States and Canada. Mar. Biol. 120: 467-478.

Arakawa O., Noguchi T., Hwang D.F., Chang D.S., Jeon J.K. and Hashimoto K. 1989. Paralytic shellfish poisoning by the mussel Mytilus edulis in Korea. In: Okaichi T., Anderson D.M. and Nemoto T. (eds), Red Tides: Biology, Environmental Science, and Toxicology. Elsevier, New York. pp. 407-410.

Balech E, 1971. Microplancton del Atlantico ecuatorial oeste (Equalant I). Servicio de Hidrografia Naval, Buenos Aires $H$ 654: 1-103.

Balech E. 1985. The genus Alexandrium or Gonyaulax of the tamarensis group. In: Anderson D.A., White A.W. and Baden D.G. (eds), Toxic dinoflagellates. Elsevier, New York. pp. 33-38.

Balech E. 1989. Redescription of Alexandrium minutum Halim (Dinophyceae) type species of the genus Alexandrium. Phycologia 28: 206-211.

Balech E. 1995. The Genus Alexandrium Halim (Dinoflagellata). Sherkin Island Marine Station, Co. Cork. 151 pp.

Balech E. and Tangen K. 1985. Morphology and taxonomy of toxic species in the tamarensis group (Dinophyceae): Alexandrium excavatum (Braarud) comb. nov. and Alexandrium ostenfeldii (Paulsen) comb. nov. Sarsia 70: 333343.

Braarud T. 1945. Morphological observations on marine dinoflagellate cultures (Porella perforata, Goniaulax tamarensis, Protoceratium reticulatum). Avh. Utgitt. Nor. Vidensk. 
Akad. Oslo Mat.-Naturvidensk K1. 11: 1-18.

Cembella A.D. and Taylor F.J.R. 1986. Electrophoretic variability within the Protogonyaulax tamarensis/catenella species complex: pyridine linked dehydrogenases. Biochem. Syst. Ecol. 14: 311-323.

Cembella A.D., Sullivan J.J., Boyer G.L., Taylor F.J.R. and Andersen R.J. 1987. Variation in paralytic shellfish toxin composition within the Protogonyaulax tamarensis/catenella species complex: red tide dinoflagellates. Biochem. Syst. Ecol. 15: $171-186$.

Chang D.S., Shin I.S., Pyeun J.H. and Park Y.H. 1987. A study on paralytic shellfish poison of sea mussel, Mytilus edulis, Korea. Bull. Korean Fish. Soc. 20: 293-299 (in Korean).

Cho C.H. 1978. On the Gonyaulax red tide in Jinhae Bay. Bull. Korean Fish. Soc. 11: 111-114. (in Korean)

Delgado M., Garces E., Vila M. and Camp J. 1997. Morphological variability in three populations of the dinoflagellate Alexandrium taylori. J. Plankton Res. 19: 749757.

Fukuyo Y., Pholpunthin P. and Yoshida K. 1988. Protogonyaulax (Dinophyceae) in the Gulf of Thailand. Bull. Plankton Soc. Japan 35: 9-20.

Fukuyo, Y. 1985. Morphology of Protogonyaulax tamarensis (Lebour) Taylor and Protogonyaulax catenella (Whedon and Kofoid) Taylor from Japanese coastal waters. Bull. Mar. Sci. 37: 529-537.

Gallacher S., Flynn K.J., Franco J.M., Brueggemann E.E. and Hines H.B. 1997. Evidence for the production of paralytic shellfish toxins by bacteria associated with Alexandrium spp. (Dinophyta) in culture. Appl. Environ. Microbiol. 63: 239-245.

Gallagher J.C. 1998. Genetic variation in harmful algal bloom species: an evolutionary ecology approach. In: Anderson D.M., Cembella A.D. and Hallegraeff G.M. (eds), Physiological Ecology of Harmful Algal Blooms. Springer, Berlin. pp. 225-242.

Hallegraeff G.M. 1993. A review of harmful algal blooms and their apparent global increase. Phycologia 32: 79-99.

Hallegraeff G.M., Bolch C.J., Blackburn S.I. and Oshima Y. 1991. Species of the toxigenic dinoflagellate genus Alexandrium in Southeastern Australian waters. Bot. Mar. 34: 575-587.

Hallegraeff G.M., Steffensen D.A. and Wetherbee R. 1988. Three estuarine Australian dinoflagellates that can produce paralytic shellfish toxins. J. Plankton Res. 10: 533-541.

Han M.-S., Jeon J.-K. and Kim Y.-O. 1992. Occurrence of dinoflagellate Alexandrium tamarense, a causative organism of paralytic shellfish poisoning in Chinhae Bay, Korea. J. Plankton Res. 14: 1581-1592.

Han M.-S., Jeon J.-K. and Yoon Y.-H. 1993. Distribution and toxin profiles of Alexandrium tamarense (Lebour) Balech (Dinoflagellata) in the southeastern coastal waters, Korea. Korean J. Phycol. 8: 7-13.

Hsu B.C.-C. 1967. Study of paralytic shellfish toxicity causative organisms in the State of Washington. Master's Thesis, University of Washington. $124 \mathrm{pp}$.

Iwasaki H. 1961. The life cycle of Porphyra tenera in vitro. Biol.
Bull. 121: 173-187.

Jeon J.K., Yi S.K. and Huh H.T. 1988. Paralytic shellfish poisoning of bivalves in the Korean waters. J. Oceanol. Soc. Korea 23: 123-129 (in Korean).

Kim C.H. and Lee J.S. 1996. Occurrence of toxic dinoflagellates and PSP toxin profiles in Alexandrium spp. from Jinhae Bay, Korea. In: Yasumoto T., Oshima Y. and Fukuyo Y. (eds), Harmful and Toxic Algal Blooms. UNESCO, Paris. pp. 61-64.

Kim C.H. and Shin J.B. 1997. Harmful and toxic red tide algal development and toxins production in Korean coastal waters. Algae 12: 269-276 (in Korean).

Kim C.H., Sako Y. and Ishida Y. 1993. Comparison of toxin composition between populations of Alexandrium spp. from geographically distant areas. Nippon Suisan Gakkaishi 59: 641-646.

Kim K.-Y. 2001. Geographical Distribution of Alexandrium tamarense/catenella Complex (Dinophyceae) in Korea Based on Morphology and Molecular Character. Master's thesis, Pukyong National University, Busan. 59 pp.

Lebour M.V. 1925. The dinoflagellates of Northern Seas. Mar. Biol. Ass. U.K., Plymouth. 250 pp.

Lee J.S., Shin I.S., Kim Y.M. and Chang D.S. 1997. Paralytic shellfish toxins in the mussel, Mytilus edulis, caused the shellfish poisoning accident at Geoje, Korea, in 1996. J. Korean Fish. Soc. 30: 158-160 (in Korean).

Lee S.G., Park J.S. and Kim H.G. 1993. Taxonomy of marine toxic flagellates occurring in the southern coastal waters of Korea. Bull. Natl. Fish. Res. Dev. Agen. 48: 1-23 (in Korean).

Lee, S.Y., Hee, H.W., Park, J.G., Lee, J.A. and Park, Y.S. 1998. Molecular phylogeny of phytoplankton isolated from red tides in southern coast of Korea. Bada 3: 90-93 (in Korean).

Loeblich III A.L. and Loeblich L.A. 1979. The systematics of Gonyaulax with special reference of the toxic species. In: Taylor D.L. and Seliger H.H. (eds), Toxic Dinoflagellate Blooms. Elsevier, New York. pp. 41-46.

Medlin L.K., Lange M., Wellbrock U., Donner G., Elbrahter M., Hummert C. and Luckas B. 1998. Sequence comparisons link toxic European isolates of Alexandrium tamarense from the Orkney isolates to toxic North American stocks. Europ. J. Protistol. 34: 329-335.

Parkhill J.-P. and Cembella A.D. 1999. Effects of salinity, light and inorganic nitrogen on growth and toxigenicity of the marine dinoflagellate Alexandrium tamarense from northeastern Canada. J. Plankton Res. 21: 939-955.

Postek M.T. and Cox E.R. 1976. Thecal ultrastructure of the toxic marine dinoflagellate Gonyaulax catenella. J. Phycol. 12: 88-93.

Schmidt R.J. and Loeblich III A.R. 1979. A discussion of the systematics of toxic Gonyaulax species containing paralytic shellfish poison. In: Taylor D.L. and Seliger H.H. (eds), Toxic Dinoflagellate Blooms. Elsevier, New York. pp. 83-88.

Scholin C.A. 1998. Morphological, genetic, and biogeographic relationships of the toxic dinoflagellates Alexandrium tamarense, A. catenella, and A. fundyense. In: Anderson D.M., Cembella A.D. and Hallegraeff G.M. (eds), Physiological 
Ecology of Harmful Algal Blooms. Springer, Berlin. pp. 13-27. Scholin C.A., Hallegraeff G.M. and Anderson D.M. 1995. Molecular evolution of the Alexandrium tamarense "species complex" (Dinophyceae): dispersal in the North American and West Pacific regions. Phycologia 34: 472-485.

Scholin C.A., Herzog M., Sogin M. and Anderson D.M. 1994. Identification of group- and strain-specific genetic markers for globally distributed Alexandrium (Dinophyceae). II. Sequence analysis of a fragment of the LSU rRNA gene. $J$. Phycol. 30: 999-1011.

Shim J.H., Shin E.Y. and Choi J.K. 1981. A taxonomical study on the dinoflagellates of the coastal waters in the vicinity of Yeosu, Korea. J. Oceanol. Soc. Korea 16: 57-98 (in Korean).

Sivonen K. 1996. Cyanobacterial toxins and toxin production. Phycologia 35: 12-24.

Sommer H. and Meyer K.F. 1937. Paralytic shellfish poisoning. Arch. Pathol. 24: 560-598.

Sournia A. 1995. Red tide and toxic marine phytoplankton of the world ocean: an inquiry into biodiversity. In: Lassus P., Arzul G., Erard E., Gentien P. and Macraillou C. (eds), Harmful Marine Algal Blooms. Lavoisier, Paris. pp. 103-112.

Steidinger K.A. 1971. Gonyaulax balechii sp. nov. (Dinophyceae) with a discussion of the genera Gonyaulax and Heteraulacus. Phycologia 10: 183-187.

Steidinger K.A. 1990. Species of the tamarensis/catenella group of Gonyaulax and the fucoxanthin derivative-containing gymnodiniods. In: Graneli F., Sundstrom B., Edler L. and Anderson D.M. (eds), Toxic Marine Phytoplankton. Elsevier, New York. pp. 11-16.

Steidinger K.A. and Moestrup Ø. 1990. The taxonomy of Gonyaulax, Pyrodinium, Alexandrium, Gessnerium, Protogonyaulax and Goniodoma. In: Graneli F., Sundstrom B., Edler L. and Anderson D.M. (eds), Toxic Marine Phytoplankton. Elsevier, New York. pp. 522-523.
Steidinger K.A. and Tangen K. 1997. Dinoflagellates. In: Tomas C.R. (ed), Identifying Marine Phytoplankton. Academic Press, San Diego. pp. 387-584.

Taylor F.J.R. 1975. Taxonomic difficulties in red tide and paralytic shellfish poison species: the "tamarensis" complex of Gonyaulax. Environ. Lett. 9: 103-119.

Taylor F.J.R. 1979. The toxigenic gonyaulacoid dinoflagellates. In: Taylor D.L. and Seliger H.H. (eds), Toxic Dinoflagellate Blooms. Elsevier, New York. pp. 47-56.

Taylor F.J.R. 1984. Toxic dinoflagellates: taxonomic and biogeographic aspects with emphasis on Protogonyaulax. In: Ragelis E.P. (ed), Seafood Toxins. American Chemical Society, Washington D.C. pp. 77-97.

Taylor F.J.R., Fukuyo Y. and Larsen J. 1995. Taxonomy on harmful dinoflagellates. In: Hallegraeff G.M., Anderson D.M. and Cembella A.D. (eds), Manual on Harmful Marine Microalgae. UNESCO, Paris. pp. 283-317.

Whedon W.F. and Kofoid C.A. 1936. Dinoflagellates of the San Francisco region. I. On the skeletal morphology of two new species, Gonyaulax catenella and G. acatenella. Univ. Calif. Publ. Zool. 41: 25-34.

Yoo J.S., Fukuyo Y., Cheun B., Lee S.G. and Kim H.G. 2000. Toxic algal bloom caused by dinoflagellate Alexandrium tamarense in Chindong Bay, Korea. J. Fish. Sci. Tech. 3: 2632.

Yoshida M. 2000. The Taxonomic Study of the Genus Alexandrium. Ph.D. Thesis, The University of Tokyo, Tokyo. 139 pp.

Yuki K. and Fukuyo Y. 1992. Alexandrium satoanum sp. nov. (Dinophyceae) from Matoya Bay, central Japan. J. Phycol. 28: 395-399.

Accepted 4 March 2002 